\title{
Modelling impacts of seasonal
}

\section{wastewater treatment plant effluent \\ permits and biosolid substitution for}

phosphorus management in catchments

and river systems

Whitehead, PG

http://hdl.handle.net/10026.1/3790

10.2166/nh.2014.100

Hydrology Research

IWA Publishing

All content in PEARL is protected by copyright law. Author manuscripts are made available in accordance with publisher policies. Please cite only the published version using the details provided on the item record or document. In the absence of an open licence (e.g. Creative Commons), permissions for further reuse of content should be sought from the publisher or author. 


\section{Hydrology Research \\ MODELLING IMPACTS OF SEASONAL WASTEWATER TREATMENT PLANT EFFLUENT PERMITS AND BIOSOLID SUBSTITUTION FOR PHOSPHORUS MANAGEMENT IN CATCHMENTS AND RIVER SYSTEMS \\ --Manuscript Draft--}

\begin{tabular}{|c|c|}
\hline Manuscript Number: & HYDROLOGY-D-12-00100R1 \\
\hline Full Title: & $\begin{array}{l}\text { MODELLING IMPACTS OF SEASONAL WASTEWATER TREATMENT PLANT } \\
\text { EFFLUENT PERMITS AND BIOSOLID SUBSTITUTION FOR PHOSPHORUS } \\
\text { MANAGEMENT IN CATCHMENTS AND RIVER SYSTEMS }\end{array}$ \\
\hline Article Type: & Research Paper \\
\hline Corresponding Author: & $\begin{array}{l}\text { paul whitehead, PhD } \\
\text { University of Oxford } \\
\text { oxford, UNITED KINGDOM }\end{array}$ \\
\hline \multicolumn{2}{|l|}{$\begin{array}{l}\text { Corresponding Author Secondary } \\
\text { Information: }\end{array}$} \\
\hline Corresponding Author's Institution: & University of Oxford \\
\hline \multicolumn{2}{|l|}{$\begin{array}{l}\text { Corresponding Author's Secondary } \\
\text { Institution: }\end{array}$} \\
\hline First Author: & paul whitehead, PhD \\
\hline \multicolumn{2}{|l|}{ First Author Secondary Information: } \\
\hline \multirow[t]{3}{*}{ Order of Authors: } & paul whitehead, PhD \\
\hline & sean comber \\
\hline & martyn futter \\
\hline \multicolumn{2}{|c|}{ Order of Authors Secondary Information: } \\
\hline Abstract: & $\begin{array}{l}\text { The issues of diffuse and point source phosphorus (P) pollution in river systems are } \\
\text { presented using a catchment model to assess nutrient behaviour, seasonal effluent } \\
\text { standards and biosolid substitution. A process based, dynamic water quality model } \\
\text { (INCA-P) has been applied to four UK catchments, namely, the Rivers Tywi, Wensum, } \\
\text { Lunan and Test, to simulate water fluxes, sediments, total phosphorus (TP) and } \\
\text { soluble reactive phosphorus (SRP) concentrations. The model has been used to } \\
\text { assess impacts of both agricultural runoff and point P sources from Waste Water } \\
\text { Treatment Plants (WWTPs) on water quality. With increasing costs for P fertilizer and P } \\
\text { reduction at WWTPs, a strategy of recycling P from WWTPs as biosolids to substitute } \\
\text { for fertilizers in vulnerable catchments has been investigated. Significant reductions in } \\
\text { P concentrations are achieved if this substitution were implemented on a large scale. } \\
\text { Reductions in SRP of between } 4 \text { and } 41 \% \text { can be achieved using this strategy. The } \\
\text { effects of implementing new WWTP standards are shown to reduce SRP by } 30 \% \text {. } \\
\text { Seasonal consent standards applied in only summer months could reduce SRP by } \\
53 \% \text { and achieve a substantial reduction in treatment costs year round. }\end{array}$ \\
\hline
\end{tabular}




\title{
MODELLING IMPACTS OF SEASONAL WASTEWATER TREATMENT PLANT EFFLUENT PERMITS AND BIOSOLID SUBSTITUTION FOR PHOSPHORUS MANAGEMENT IN CATCHMENTS AND RIVER SYSTEMS
}

\author{
P.G Whitehead ${ }^{1}$, M.N. Futter ${ }^{2}$, S. Comber ${ }^{3}$, D. Butterfield ${ }^{1}$, L. Pope ${ }^{4}$, R. Willows ${ }^{4}$ \\ and C. Burgess ${ }^{4}$ \\ ${ }^{1}$ School of Geography and the Environment, University of Oxford, South Parks Road, Oxford, \\ OX1 3QY: email paul.whitehead@ouce.ox.ac.uk \\ ${ }^{2}$ Department of Aquatic Science and Assessment, Swedish University of Agricultural Sciences, \\ SE-75007 Uppsala, Sweden \\ ${ }^{3}$ Plymouth University, Drakes Circus, Plymouth, PL4 8AA \\ ${ }^{4}$ Environment Agency, Thames Regional Office, Kings Meadow House, Kings Meadow Road, \\ Reading, Berkshire, RG1 8DQ
}

\begin{abstract}
The issues of diffuse and point source phosphorus $(\mathrm{P})$ pollution in river systems are presented using a catchment model to assess nutrient behavior, seasonal effluent standards and biosolid substitution. A process based, dynamic water quality model (INCA-P) has been applied to four UK catchments, namely, the Rivers Tywi, Wensum, Lunan and Test, to simulate water fluxes, sediments, total phosphorus (TP) and soluble reactive phosphorus (SRP) concentrations. The model has been used to assess impacts of both agricultural runoff and point $\mathrm{P}$ sources from Waste Water Treatment Plants (WWTPs) on water quality. With increasing costs for P fertilizer and P reduction at WWTPs, a strategy of recycling P from WWTPs as biosolids to substitute for fertilizers in vulnerable catchments has been investigated. There would be significant reductions in $\mathrm{P}$ concentrations in these rivers if this substitution were implemented on a large scale, as biosolid $\mathrm{P}$ can be significantly less soluble than standard superphosphate fertilizers. Reductions in SRP concentrations of between 4 and $41 \%$ can be achieved using this strategy. The magnitude of the reductions is highly dependent on the nature of the river system and land use; upland largely unimproved pastures predicting less reductions in water $\mathrm{P}$ concentrations than lowland heavily fertilised and improved pastures The effects of implementing new effluent discharge standards with high levels of P removal have been investigated for the River Wensum and are shown to reduce SRP by $30 \%$ in the river system. As the cost of P reduction at the WWTPs is high, an alternative strategy using seasonal consent standards applied in only summer months has been assessed. The modelling suggests that such an approach could reduce SRP by 53\% compared to the current treatment levels and achieve a substantial reduction in treatment costs year round.
\end{abstract}

\section{INTRODUCTION}

Sustainable food production and water quality degradation as a result of excessive nutrient inputs are two of the biggest problems facing society today. Global food production is ultimately dependent on phosphorus (P) supply (Cordell and White, 2011). Increasing concerns are being expressed about "peak phosphorus", or the idea that global P reserves are insufficient to support food production in the future. Furthermore, once $\mathrm{P}$ enters surface waters via runoff from the terrestrial environment or from waste water treatment plants (WWTP) (Comber et al., 2010), it can have adverse effects on water quality. Excessive P inputs have been linked to eutrophication 
47 in freshwater (Carpenter et al. 1998, White and Hammond 2008) and marine (Nixon, 1995, 48 Alexander et al. 2008) environments. Eutrophication effects are more pronounced in summer In Europe, legislation including the Water Framework (WFD; EU 2000), Urban Wastewater Treatment (UWWTD; EU1991) and Habitats Directives (EU, 1992) set objectives for wastewater or receiving water quality with respect to P. The WFD sets Environmental Quality Standards (EQS) for P concentration in rivers and lakes (UKTAG 2013). The current regulatory environment poses a major challenge to the water sector in the UK with approximately 700 WWTP in the UK planning or already implementing measures to reduce P loads to vulnerable water bodies. Approximately 1,000 additional WWTP are predicted to be causing downstream EQS exceedences owing to their contributions alone (Comber et al., 2010) without considering any upstream inputs from agriculture or other WWTP. It has become apparent that a catchmentbased approach is required to improve water quality and ecological status using a combination of measures to reduce agricultural and wastewater derived inputs, including consideration of options such as seasonal-based permitting of $\mathrm{P}$ discharges from WWTP. Currently water companies are obliged to meet annual average targets of typically 1 or $2 \mathrm{mg}-\mathrm{P} / 1$ all year round, depending on the size of WWTP and sensitivity of the receiving water. However, a more beneficial ecological outcome may be derived from applying tighter permits during summer months when biological activity is at its highest, then allow a more relaxed permit during the winter when higher flows and lower productivity ensures that the impacts of $\mathrm{P}$ derived from WWTP would be significantly reduced.

Approximately $90 \%$ of the $20 \mathrm{Mt} / \mathrm{yr} \mathrm{P}$ used in global agricultural fertilizer is currently derived from mineral sources (Cordell et al. 2009), predominantly from Morocco, the United States and China. There are significant monetary and carbon costs associated with $\mathrm{P}$ refining and transport to areas where it is applied as fertilizer (Cordell et al. 2009). Recycling P removed during wastewater treatment to land as agricultural fertilizer has potential economic, environmental and societal benefits. The possible benefits of utilizing biosolids as a fertilizer are explored as scenarios in the catchment modeling undertaken here.

In the UK approximately one million tonnes of dry solids are produced annually from WWTP (UKWIR, 2006). This amount is likely to increase over the next 10 years as a greater proportion of sewage is treated, higher treatment standards are applied under the UWWTD and WFD and population increases. The main disposal route for sewage sludge is recycling to land as biosolids; accounting for approximately $70 \%$ of the sludge produced in the UK (CEEP, 2009) and is considered by the UK government as the Best Practicable Environmental Option (BPEO). Recycling to agricultural land is the most sustainable option as it enables nutrients to be recycled to maintain soil fertility and to provide farmers with an alternative to inorganic fertilizers and manures which may not have the same environmental benefits and are more expensive. Approximately $44 \%$ of sludge used on agricultural land is anaerobically digested; the majority of this is applied as liquid rather than dewatered sludge cake. Treated liquid sludges (3-6\% dry solids) are applied to both arable and grassland whilst dewatered sludges (25-38\% dry solids) are usually restricted to arable land where they can be ploughed or incorporated into the soil (UKWIR, 2006). 
A number of studies have been undertaken assessing the nutrient availability of biosolids. In particular, reported data suggests that $\mathrm{P}$ present in biosolids derived from sewage sludge, is less easily leached from soils after application compared with inorganic fertilizers (Miller and O'Connor 2009). Phosphorus leaching has also been reported to be low in Coastal Plain soils amended with biosolids whose high concentrations of $\mathrm{Al}$ and Fe increased $\mathrm{P}$ sorption and reduce P solubility (Elliot et al., 2002). Similar results were found by Siddique et al. (2000) in a study on soils whose surface horizon texture was loam. Significantly greater amounts of P leached from inorganic fertilizer-amended soil than sludge-amended soil. The difference in P mobility was explained by the lower P solubility in the sludge compared with the fertilizer. The use of biosolids as a fertilizer close to vulnerable water bodies could therefore assist in reducing agricultural losses of $\mathrm{P}$.

The greatest risk for surface water contamination from $\mathrm{P}$ is particulate-P from soil erosion (with its associated sorbed-P) by runoff. Biosolids improve soil structure and thus reduce the risk of runoff (Evans, 2010). This presents a possible trade-off; organic matter addition promoting stable soil structure and reducing phosphate losses as particulate-P, versus the risk of increasing bicarbonate-extractable $\mathrm{P}$ above the threshold where breakthrough becomes a risk. The risk of water pollution by biosolids derived phosphate has been extensively studied by Withers and coworkers (e.g. UKWIR, 1997). Animal manure is a greater risk than sludge biosolids because they contain more soluble-P. Biosolids have been eluted as a result of the water-borne transfer process, which removes soluble-P to the liquid phase and the solid-phase-P has been stabilised by biosolids treatment. Smith et al. (2000) added different forms of biosolids to two different moist soils (sandy loam at $\mathrm{pH} 6.2$ and calcareous clay at $\mathrm{pH} 8.1$ ) and measured the change in sodium bicarbonate extractable $\mathrm{P}$ with time. The majority of the re-equilibration of $\mathrm{P}$ between the biosolids and the soil occurred within a few hours, followed by a much slower increase in extractable-P, which continued for more than 60 days. The pattern of change was related to the type of soil and its starting content of bicarbonate extractable P. It was also related to the type of treatment to which the biosolids had been subjected. Availability of biosolids-P was in the order thermally dried $<<$ cake<liquid. It has been reported that lime-stabilised sludge can leach greater proportions of phosphorus than other biosolids (Kostyanovsky et al., 2011). However, recent data suggests that this form of sludge treatment is becoming less popular in the UK, with anaerobically digested sludge now being favoured (UKWIR, 2006). Injection of sludge into soils is also now the preferred option for application, rather than surface spreading, as it both reduces runoff likelihood as well as reducing odour issues (UKWIR 1997).

Although some leaching has been detected in soils amended with lime stabilized biosolids (Kostyanovsky et al., 2011) attributed to the colloidally facilitated transport of organic P and mineralization; the high binding capacity of the biosolids were considered to pose little risk of $\mathrm{P}$ leaching into groundwater. Most of the anaerobic digested biosolids $\mathrm{P}$ was complexed in $\mathrm{Al}$ and $\mathrm{Fe}$ forms with $\mathrm{P}$ in the lime stabilized biosolids associated with $\mathrm{Ca}$.

Accurate scenario modeling techniques are needed to explore the potential effectiveness of programs of measures considered for application under the WFD. Here we assess possible scenarios for catchment-scale $\mathrm{P}$ management using INCA-P, a process based, catchment-scale model of $\mathrm{P}$ dynamics (Wade et al. 2002). In particular, we simulate the impacts of two 
management practices which may be applied within a catchment to control in-river $\mathrm{P}$ concentrations. These two management strategies include using different types of fertilizers with varying $P$ leaching rates and seasonal end of pipe control of WWTP effluent concentrations via seasonal permits, to limit $\mathrm{P}$ concentrations in UK rivers under low flow summer conditions, when ecological impacts are most significant. The model was used for scenario evaluation in four catchments of varying typology and geographic location: the Lunan in Scotland, the Wensum in Norfolk, the Test in Southern England and the Tywi in Wales.

\section{METHODOLOGY}

\section{INCA model}

In order to model P in UK catchments, the dynamic, process based model INCA (Integrated Catchment) model has been used. This model is semi- distributed and incorporates the key processes operating in both terrestrial and aquatic environments. The philosophy of the INCA model is to provide a process-based representation of the factors and processes controlling flow and water quality dynamics in both the land and in-stream components of river catchments, whilst minimising data requirements and model structural complexity (Whitehead et al., 1998a, b). As such, the INCA model produces daily estimates of discharge, and stream water quality concentrations and fluxes, at discrete points along the main channel of a river. The model is semi-distributed, so that spatial variations in land use and management can be taken into account, although the hydrological connectivity of different land use patches is not modelled in a fullydistributed manner. Rather, the hydrological and nutrient fluxes from different land use classes and sub-catchment boundaries are modelled simultaneously and information fed sequentially into a multi-reach river model. The INCA model, in its various forms, has been extensively applied across Europe (UK, France, Sweden, Denmark, Norway, Austria, Finland, Romania, and Turkey) and around the world in Nepal, Brazil and Canada. The major applications of INCA have been published to date in three special volumes of International Journals, namely, Hydrology and Earth System Sciences, 2002, 6, (3), Science of the Total Environment, 2006, 365, (1-3) and Hydrological Research, 2009, 40 (2-3).

In this study, we have used the INCA-P version of the model. INCA-P is a physical, processbased model, as shown in Figure 1, which simulates flow, sediment, phosphorus (TP, PP and SRP) in soils, groundwaters, streams and sediments (Wade et al., 2002b, 2009, Whitehead et al. 2011, 2013, Crossman et al. 2012, 2013). It has both a land component and a river component, allowing it to track $\mathrm{P}$ inputs which flow into the river from the land surface throughout the catchment. INCA-P is a distributed model and takes account of spatial variations in land use, vegetation and hydrology by dividing the catchment into sub-catchments or into a multibranch network of tributaries and streams that flow into a main river system (Whitehead et al., 2011). The INCA model has partitioning algorithms which calculate the proportions of $\mathrm{P}$ adsorbed to the soil, something many models do not have, thus making simulations more accurate. It also has equilibrium equations controlling the water- sediment exchange based on a Langmuir isotherm approach, so that a realistic exchange of $\mathrm{P}$ between water phase and solid phases is possible (Wade et al, 2009). 


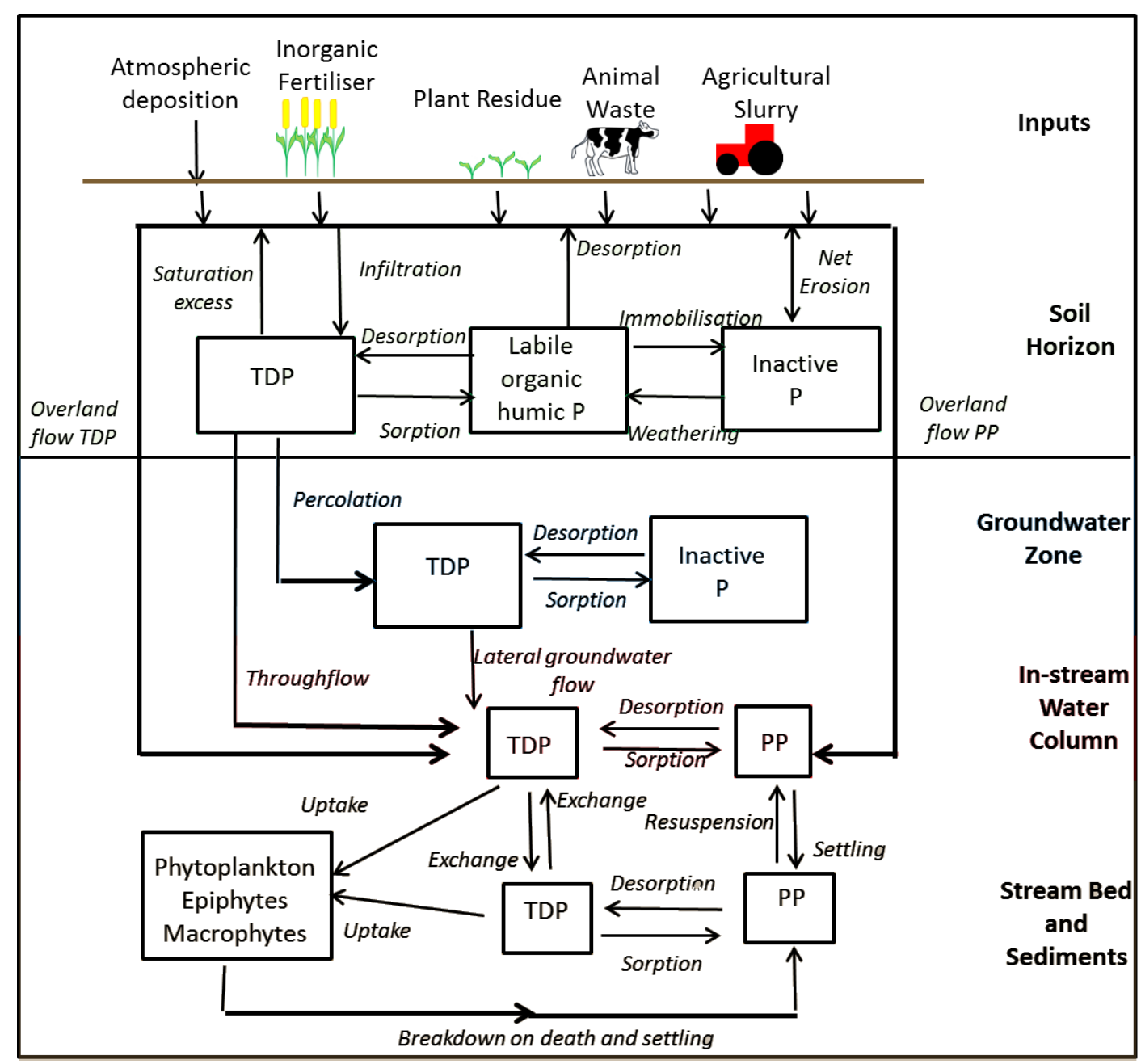

Figure 1 The INCA-P Model nutrient flows and process controls

\section{Modelled Catchments}

The model has been set up for four river systems in the UK, as shown in Figure 2, including the River Wensum in East Anglia (INCA-P reaches shown in Figure 3), the River Test in Southern England, the River Tywi in South Wales and the River Lunan in South-Eastern Scotland. The four river systems represent a spectrum of catchment types and cover different $\mathrm{P}$ leaching regimes as well as differing soils, geology and land use (Table 1). The River Tywi (Wales) is an upland catchment with more acidic soils and mostly agriculture-derived $\mathrm{P}$ inputs, whereas the River Test (England) is a high status chalk catchment dominated by grassland with some significant WWTP inputs. The River Wensum (England) is a mixed arable catchment and the Lunan (Scotland) is a rural arable and peri-urban catchment with significant non-sewered $\mathrm{P}$ inputs from septic tanks. All the catchments have direct discharges from WWTP and these are incorporated into the model reach structure. Observed flow and water quality data at a wide range of monitoring locations, and managed by the UK Environment Agency and the Scottish Environmental Protection Agency (SEPA), have been used to calibrate the model parameters. To 
provide consistency and allow comparison across catchments, fertilizer applications were assumed to take place in each catchment at the same time of year in the spring.

\section{Table 1 Summary of catchment characteristics}

\begin{tabular}{|c|c|c|c|c|}
\hline Catchment & Test & Tywi & Wensum & Lunan \\
\hline Area $\left(\mathrm{km}^{2}\right)$ & 1108 & 1090 & 646 & 66 \\
\hline $\begin{array}{l}\text { Predominant } \\
\text { land use }\end{array}$ & $\begin{array}{l}\text { Chalk, groundwater } \\
\text { dominated. Cereal } \\
\text { /grassland/dairy }\end{array}$ & $\begin{array}{l}\text { Peaty upland } \\
\text { soft water, low } \\
\text { pH } \\
\text { Rough grazing }\end{array}$ & $\begin{array}{l}\text { Chalk/sand/loam } \\
\text { Mostly arable, } \\
\text { cereal and root } \\
\text { crop production }\end{array}$ & $\begin{array}{l}\text { Scottish } \\
\text { lowland } \\
\text { catchment }\end{array}$ \\
\hline P sources & $\begin{array}{l}\text { Diffuse agriculture, } \\
\text { cress beds, WWTP } \\
\text { (Andover/Romsey + } \\
\text { several smaller ones) }\end{array}$ & $\begin{array}{l}\text { Mostly diffuse } \\
\text { with a few } \\
\text { smaller WWTP } \\
\text { inputs - }\end{array}$ & $\begin{array}{l}\text { Diffuse } \\
\text { agriculture } \quad+ \\
\text { WWTP }\end{array}$ & 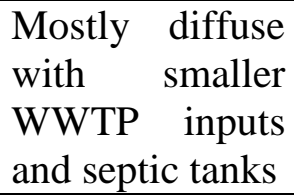 \\
\hline WWTP data & $\begin{array}{l}\text { Mains sewerage for } \\
84,000 \text { population, } \\
\text { across } 10 \text { main } \\
\text { WWTP, biggest ca. } \\
50,000 \text { (Andover) }\end{array}$ & $\begin{array}{l}\text { Main sewerage } \\
\text { for population } \\
\text { of } 5560 \text { in } 2 \\
\text { main works } \\
\text { (Llandovery and } \\
\text { Llandeilo) }\end{array}$ & $\begin{array}{l}\text { Mains sewerage } \\
\text { for } 49,000 \\
\text { population, } \\
\text { across 10 main } \\
\text { WWTP, biggest } \\
\text { ca.21,000 } \\
\text { (Dereham) }\end{array}$ & $\begin{array}{l}\text { Minor } \\
\text { discharges plus } \\
\sim 850 \quad \text { septic } \\
\text { tanks }\end{array}$ \\
\hline
\end{tabular}




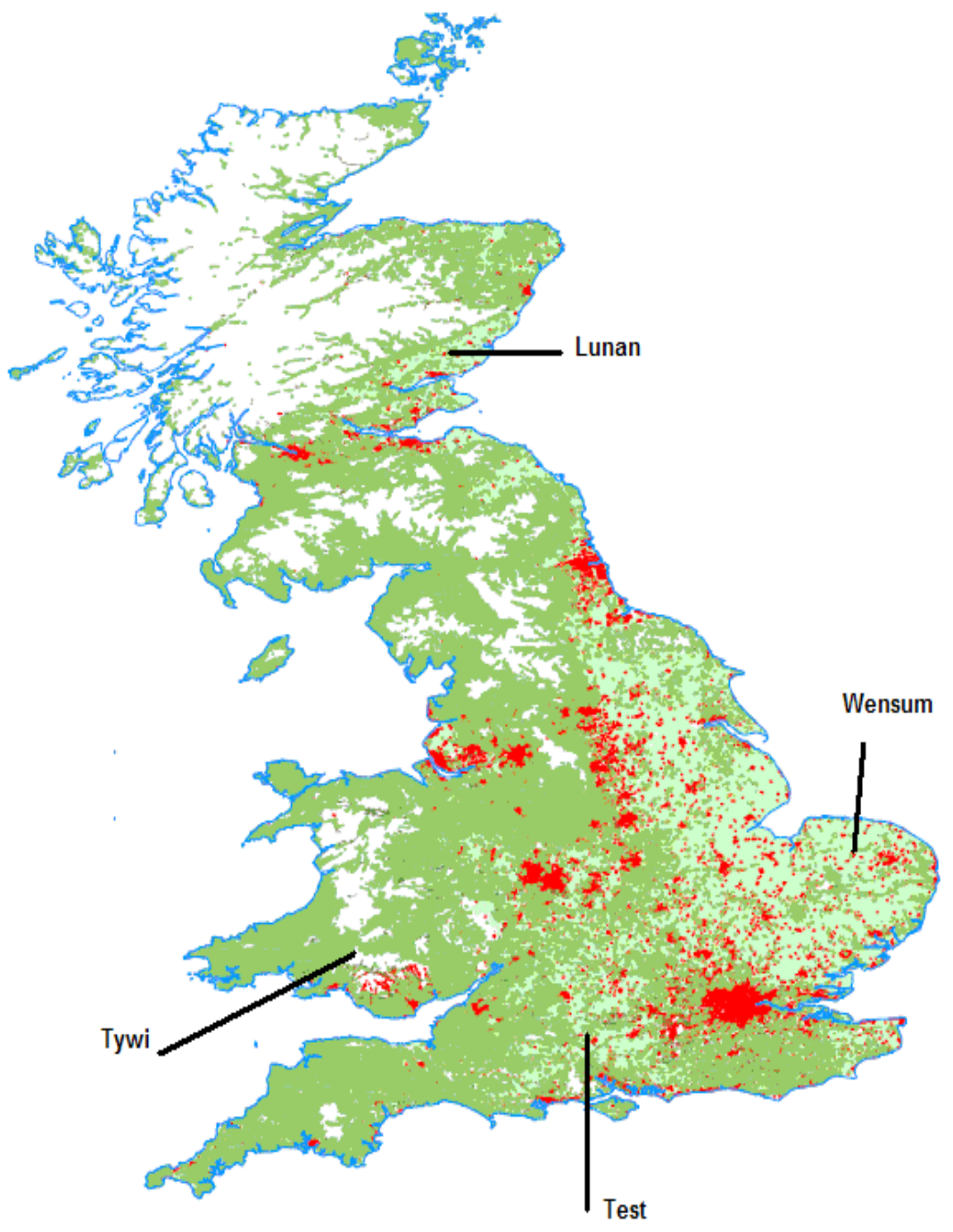

Figure 2 UK map showing locations of the four rivers modeled and also land use (Red areas are urban, light green areas are arable and darker green are pastures) 


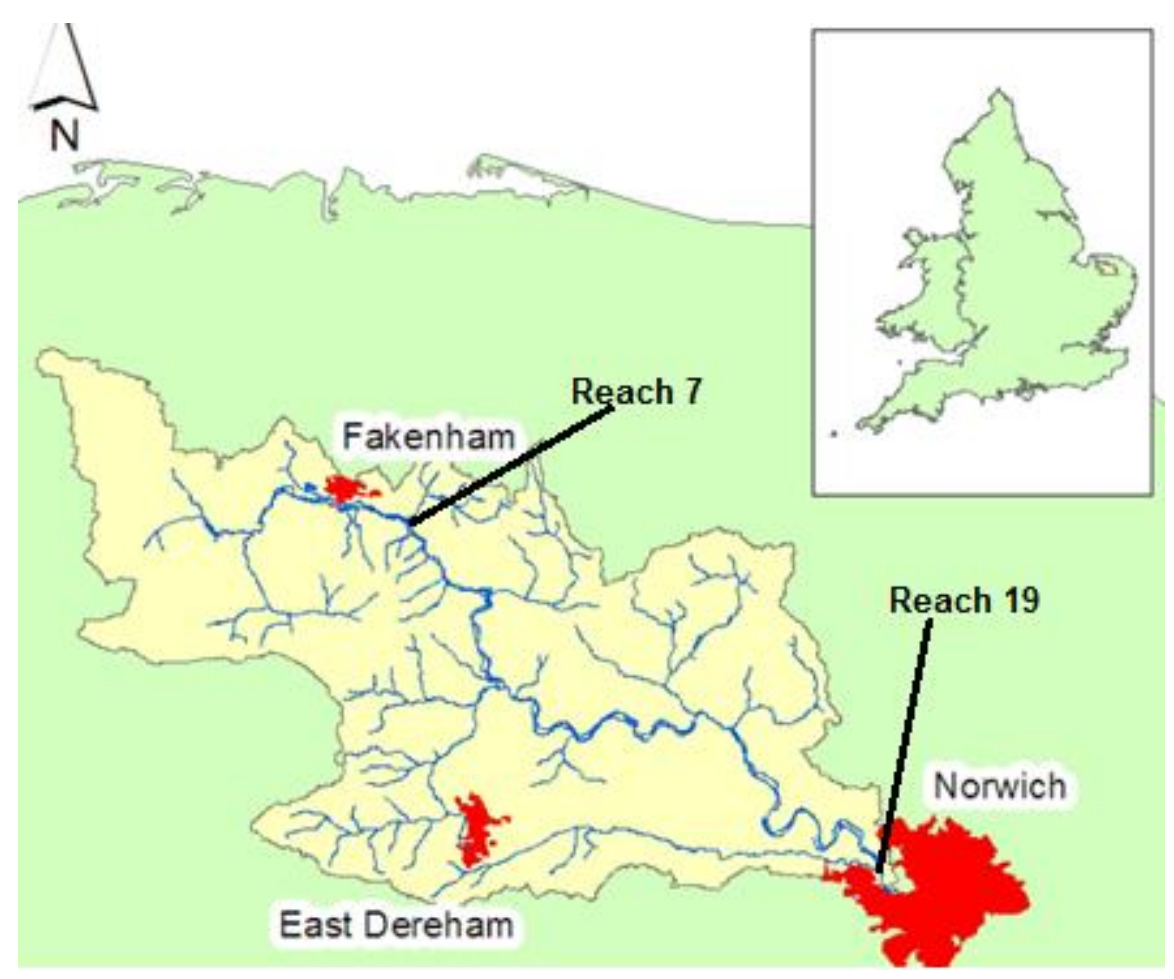

Figure 3 River Wensum Catchment in Eastern England

\section{SCENARIO STRATEGY}

Environmental legislation is now driving investment to reduce $\mathrm{P}$ discharges to surface waters via the UWWTD which sets numeric annual average TP concentrations of $2 \mathrm{mg} / \mathrm{l}$ for works serving populations between 10,000 to 100,000 and $1 \mathrm{mg} / \mathrm{l}$ for works serving greater than 100,000 persons. Other permits for $1 \mathrm{mg} / \mathrm{l}$ are also set for discharges to sensitive water bodies designated under the Birds and Habitats Directive or WFD. For each catchment modelled, effluent P concentrations were set to reflect those needed to meet the annual average $\mathrm{P}$ permit values. The current Best Available Technique for $\mathrm{P}$ reduction is considered to be dosing with iron or aluminium salts to meet $1 \mathrm{mg} / \mathrm{l} \mathrm{TP}$. Where there is no legislative driver (e.g. UWWTD) the concentrations of phosphorus are rarely measured in WWTP effluents. Consequently for smaller WWTP across the modelled catchments there is little reported data as consents for P discharge are typically only applied to works serving populations greater than 10,000. Consequently a default of $4.53 \mathrm{mg}-\mathrm{P} / \mathrm{l}$ has been applied to any non-consented discharge. This value was derived from compiling all available effluent quality data and taking a mean concentration (Comber et al., 2010). For the Test, Lunan and Tywi catchment models WWTP effluents were set to their current (as of 2010) permitted/consented concentration using data supplied by the individual water companies.

With INCA-P set up for the four catchments, a number of scenarios were run to determine the impact of different agricultural and WWTP management scenarios on P discharge to receiving waters. For each of the catchments land use was kept constant as were the fertilizer application times and rates. The only variable changed was the type of fertilizer applied and its solubility. The solubility of the different forms of biosolid that are available and those of the standard inorganic $\mathrm{P}$ are provided in Table 1. Three types of $\mathrm{P}$ fertilizer and biosolids substitution were 
used in the scenarios, namely a base case, assuming use of inorganic phosphorus fertilizer, a scenario with 50\% substitution with lime stabilised biosolids and a scenario with 50\% substitution with digested cake biosolids.

\section{Seasonal Consent Conditions}

Previous and current $\mathrm{P}$ permits for the Wensum are shown in Table 2 and show the increase in permits applied from 2010 onwards, reflecting the agreed investment to reduce $\mathrm{P}$ loads to the river. In order to determine the contribution from WWTP to total catchment P loads, one scenario was run with effluent $\mathrm{P}$ levels set to zero, so effectively removing point sources of $\mathrm{P}$ completely. Permitted $\mathrm{P}$ values are based on achieving an annual average concentration, however, for the purpose of catchment management and seeking to achieve good ecological status, the model simulations were run by setting the mean effluent TP concentrations to 0.25 $\mathrm{mg} / \mathrm{l}$ during summer when biological activity is at its peak (April to September) and $2 \mathrm{mg} / \mathrm{l}$ during winter (October to March) (Table 3). For these scenarios the diffuse agricultural inputs were fixed at the baseline scenario where only inorganic P fertiliser is used within the catchment.

Table 2 Wensum catchment WWTP data

\begin{tabular}{|c|c|c|c|c|c|}
\hline $\begin{array}{l}\text { WWTP } \\
\text { within } \\
\text { Wensum } \\
\text { catchment }\end{array}$ & Population & $\begin{array}{l}\text { Effluent } \\
\text { flow }^{1} \\
\left(\mathbf{m}^{3} / \text { day }\right)\end{array}$ & $\begin{array}{l}\text { 2005- } \\
2010 \\
\text { permit } \\
\text { (mg/l P) }\end{array}$ & $\begin{array}{l}2010 \\
\text { onwards } \\
\text { permit } \\
(\mathrm{mg} / \mathrm{l} \mathbf{P})\end{array}$ & $\begin{array}{l}\text { Effluent } \\
\text { quality } \\
\text { without a } \\
\text { permit } \\
\text { imposed } \\
\text { (mg/l P) }\end{array}$ \\
\hline WWTP1 & 2,445 & 690 & & 2.5 & $4.53^{3}$ \\
\hline WWTP2 & 21,333 & 3,769 & 2 & 1 & $5.92^{2}$ \\
\hline WWTP3 & 601 & 160 & - & 2 & $4.53^{3}$ \\
\hline WWTP4 & 16,069 & 3,300 & 2 & 1 & $4.32^{3}$ \\
\hline WWTP5 & 1,144 & 299 & - & 1 & $4.53^{3}$ \\
\hline WWTP6 & 620 & 150 & - & - & $4.53^{3}$ \\
\hline WWTP7 & 3,487 & 720 & - & 1 & $4.53^{3}$ \\
\hline WWTP8 & 1,159 & 262 & - & 1 & $4.53^{3}$ \\
\hline WWTP9 & 3839 & 850 & - & 1 & $4.53^{3}$ \\
\hline WWTP10 & 612 & 227 & - & 1 & $4.53^{3}$ \\
\hline
\end{tabular}

${ }^{1}$ Permitted dry weather flow. ${ }^{2}$ Measured data. ${ }^{3}$ mean of data reported from Comber et al., (2010)

Table 3 Wensum Catchment Scenarios

\begin{tabular}{|c|c|c|c|c|}
\hline & \multicolumn{3}{|c|}{ Permit } & Diffuse \\
Scenario & WWTP2 & WWTP4 & $\begin{array}{c}\text { Remaining } \\
\text { WWTPs }\end{array}$ & $\begin{array}{c}\text { agricultural } \\
\text { inputs }\end{array}$ \\
\hline
\end{tabular}




\section{SIMULATION AND SCENARIO RESULTS}

The INCA-P outputs were compared with measured phosphorus concentrations reported by the Environment Agency (Tywi, Test, Wensum) and Scottish Environmental Protection Agency (SEPA) for the Lunan catchment. An example of the outputs is provided in Figure 4 for the Lunan catchment. For all catchments an acceptable agreement was found based on baseline runs simulating current catchment dynamics. This provided confidence in applying the identified scenarios to the four catchments.

Simulations suggested that biosolid substitution would reduce in-river $\mathrm{P}$ concentrations in the four study catchments (Figure 5, Table 3). The effect is most pronounced during high flow conditions when diffuse $\mathrm{P}$ is being flushed into the river system. There are some noteworthy contrasts in the percentage $P$ reduction between rivers (Table 3 ). In all cases, the replacement of inorganic fertilizer with biosolids produces a reduction in river $\mathrm{P}$ concentrations. Concentration reductions range from around $5 \%$ in the River Test to approximately $35 \%$ in the Tywi, with the Wensum and Lunan both displaying decreases of approximately 10\%. An overall decrease in riverine $\mathrm{P}$ concentration is to be expected given the reduced solubility of $\mathrm{P}$ associated with biosolids. The variation between catchments is likely to be a result of the dominance of agricultural inputs within the Tywi catchment, and, therefore, any reduction in diffuse agricultural inputs will result in significant reductions in in-stream P concentrations. 

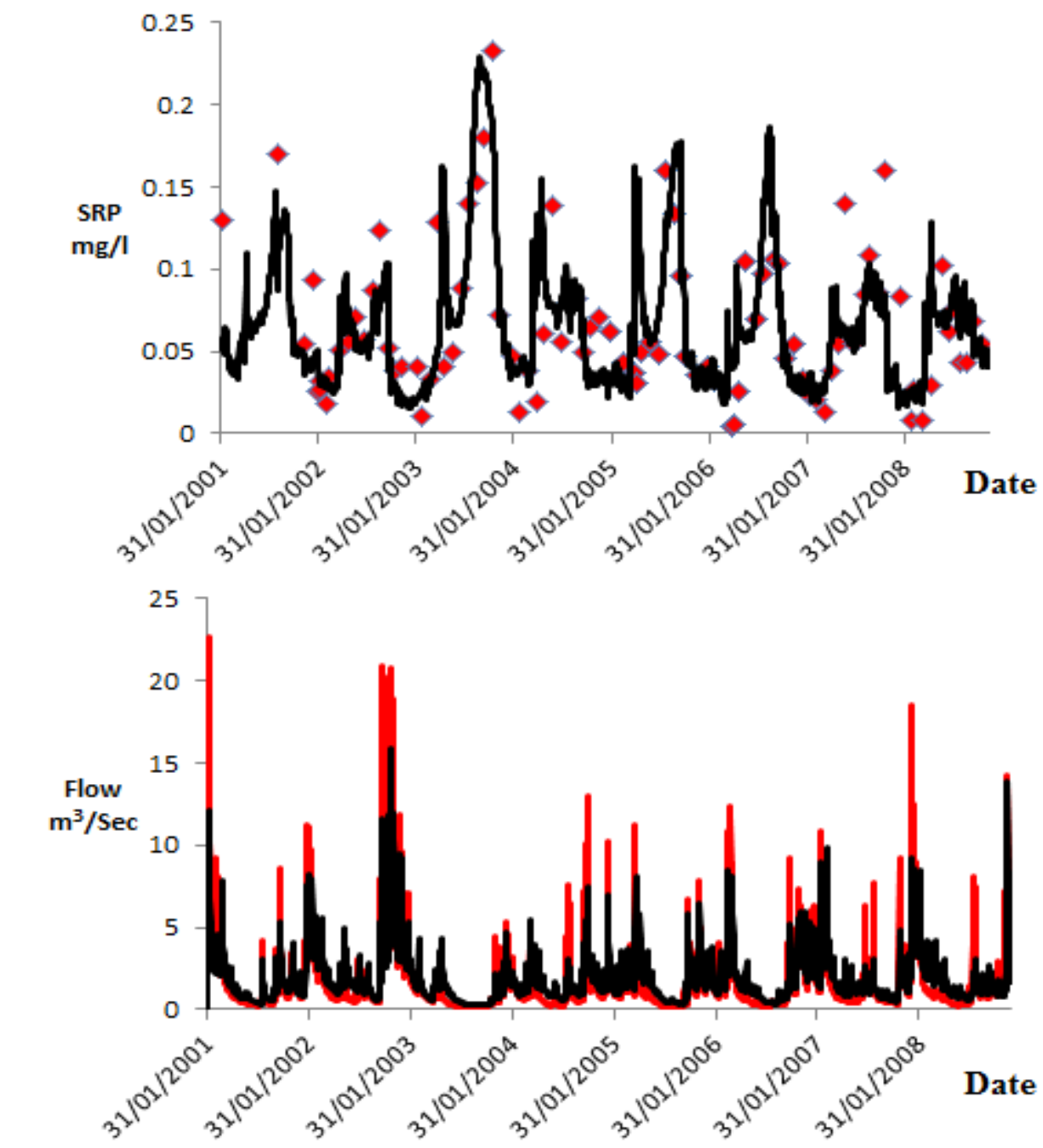

Figure 4 Simulated (Black line) and Observed (Red line) for Flow and SRP in the River Lunan 


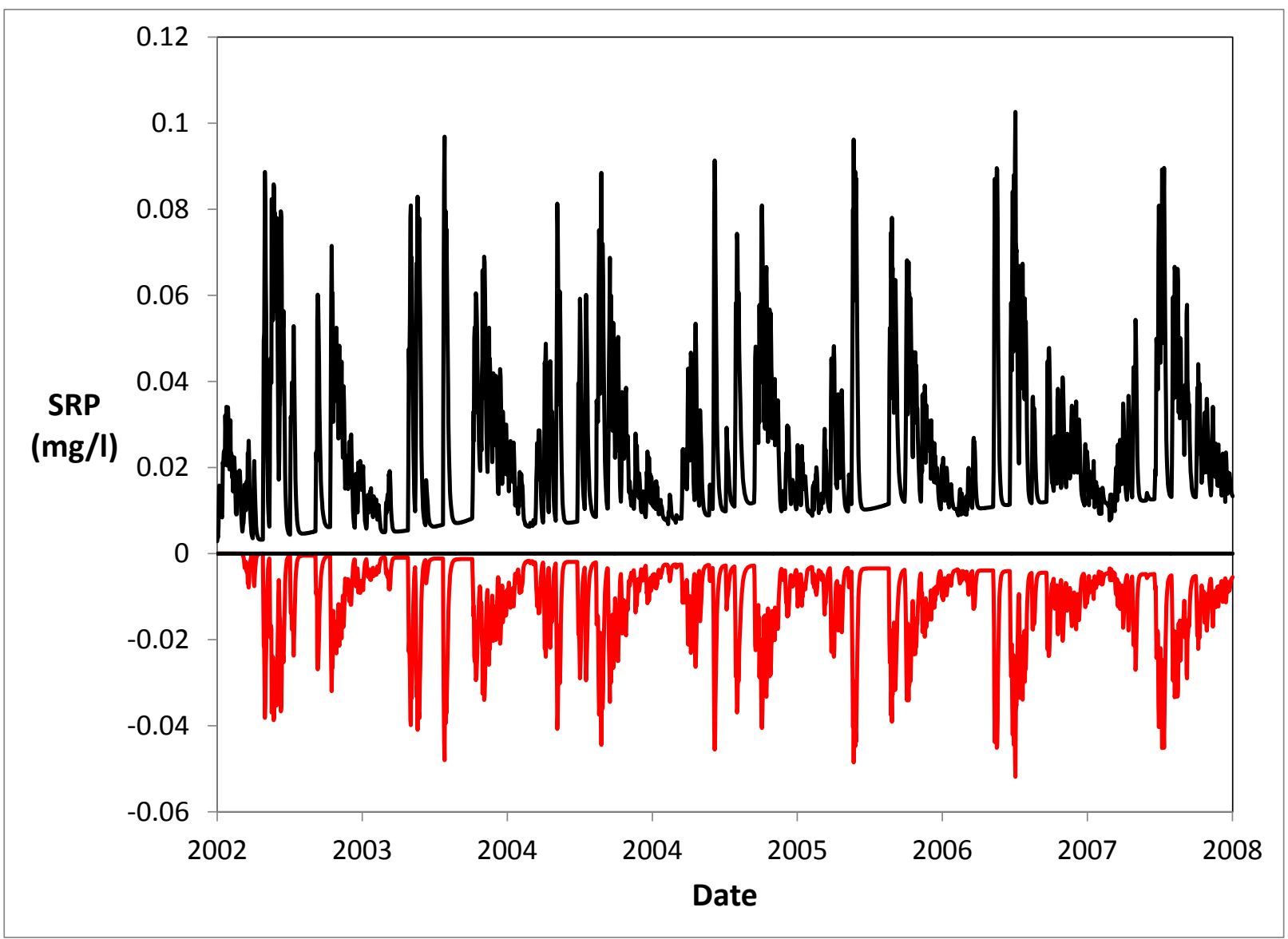

Figure 5 INCA-P output for River Tywi showing baseline Superphosphate (black line) and expected reduction in SRP (red line) that could be achieved with $50 \%$ of Inorganic P fertilizer replaced with Biosolids (digested cake)

Table 4 Percentage Reductions in TP and SRP Concentrations from Biosolid Substitution at the Outflow of Four River Catchments

\begin{tabular}{|l|l|l|l|l|}
\hline & \multicolumn{2}{|c|}{$\begin{array}{l}\text { TP Concentration Percentage } \\
\text { Reduction }\end{array}$} & $\begin{array}{l}\text { SRP Concentration Percentage } \\
\text { Reduction }\end{array}$ \\
\hline & $\begin{array}{l}\text { Lime } \\
\text { Stabilised cake }\end{array}$ & Digested Cake & $\begin{array}{l}\text { Lime } \\
\text { Stabilised cake }\end{array}$ & Digested Cake \\
\hline Tywi & 35.1 & 41.0 & 36.0 & 41.2 \\
\hline Lunan & 11.3 & 12.1 & 11.2 & 12.1 \\
\hline Wensum & 7.9 & 10.0 & 4.5 & 6.1 \\
\hline Test & 4.1 & 4.3 & 4.1 & 4.4 \\
\hline
\end{tabular}

Agricultural Impacts, Effluent Treatment and Seasonal Consent Standards

Table 4 shows the scenarios modelled for the Wensum, which include the present permitting conditions as well as the impact of seasonal permits (summer permits set between April and September inclusive). The first scenario assumes the current operating plan. The second scenario 
assumes a summer permit of $2 \mathrm{mg}-\mathrm{P} / \mathrm{l}$ for the all the works during the summer. During winter it is assumed that there are no permits for the smaller works. In the third scenario it is assumed that two large works (WWTP 2 and 4) are reduced to $1 \mathrm{mg} / 1$ with no permits for the smaller works in winter. The final scenario explored the impact of permits lower than the tightest UWWTD value for the two largest works $(0.25 \mathrm{mg}-\mathrm{P} / \mathrm{l})$ for the summer months and no permit for smaller works in winter.

308 310 311

The data in Tables 5 and 6 below show how significant the influence of the WWTP are on two reaches, one of which is downstream of WWTP4 below Fakenham (Reach 7, Figure 2) and the other is at the downstream reach of the Wensum at Norwich (Reach 19, Figure 2). Under current permitting conditions (2010 onwards) winter river P concentrations are close to the high quality EQS of $0.05 \mathrm{mg} / 1 \mathrm{SRP}$, whereas summer concentrations are above the EQS. Setting a $1 \mathrm{mg}-\mathrm{TP} / \mathrm{l}$ summer permit would reduce in-stream SRP concentrations to close to the EQS. If effluents at the two largest works were reduced to $0.25 \mathrm{mg} / \mathrm{l}$, the instream concentrations fall well below the EQS in summer. These reductions are of the order of $30 \%$ and $50 \%$ during the summer months. However, the winter concentrations rise because the standards are relaxed at the other WWTPs and this amounts to an increase of $33 \%$ at reach 19, although the instream concentrations are still within the high quality EQS. The simulations for the Wensum therefore suggest that certain benefits may be derived from seasonal permits particularly if improved phosphorus removal (beyond UWTTD requirements) at WWTP can be cost-effectively achieved during summer months. Also, Figure 5 suggests that reductions in the summer months are approximately proportional to SRP concentration.

Table 5 SRP concentrations simulated under the varying seasonal scenarios compared against 2010 on going permit conditions - Scenario1 (\% reduction in brackets)

\begin{tabular}{|l|c|c|c|c|c|}
\hline & \multicolumn{2}{|l|}{$\begin{array}{l}\text { WWTP 2 \& 4 } \\
\text { effluent P } \\
\text { concentration } \\
(\mathrm{mg} / \mathrm{l})\end{array}$} & \multicolumn{2}{l|}{$\begin{array}{l}\text { Summer SRP } \\
\text { concentration (mg/l) }\end{array}$} & \multicolumn{2}{l|}{$\begin{array}{l}\text { Winter SRP } \\
\text { Concentrations (mg/l) }\end{array}$} \\
\hline & 2 & Norwich & Fakenham & Norwich & Fakenham \\
\hline Scenario 1 & 2 & $\begin{array}{l}0.073 \\
0.084\end{array}$ & $\begin{array}{l}0.040 \\
0.044\end{array}$ \\
\hline Scenario 2 & 1 & $\begin{array}{c}0.073 \\
(0)\end{array}$ & $\begin{array}{c}0.084 \\
(0)\end{array}$ & $\begin{array}{c}0.053 \\
(+33.5)\end{array}$ & $\begin{array}{c}0.049 \\
(+12.5)\end{array}$ \\
\hline Scenario 3 & & $\begin{array}{c}0.051 \\
(-30.4)\end{array}$ & $\begin{array}{c}0.053 \\
(-36.4)\end{array}$ & $\begin{array}{c}0.053 \\
(+33.5)\end{array}$ & $\begin{array}{c}0.049 \\
(+12.5)\end{array}$ \\
\hline Scenario 4 & 0.25 & $\begin{array}{c}0.034 \\
(-53.1)\end{array}$ & $\begin{array}{c}0.031 \\
(-63.7)\end{array}$ & $\begin{array}{c}0.053 \\
(+33.5)\end{array}$ & $\begin{array}{c}0.049 \\
(+12.5)\end{array}$ \\
\hline
\end{tabular}

\section{Note: current permitting conditions apply to other WWTP}

Progressive reductions in agricultural $\mathrm{P}$ fertiliser inputs in the River Wensum were simulated. Results showed that reducing diffuse agricultural $\mathrm{P}$ fertiliser, whilst leaving WWTP inputs at current 2010 onwards levels, exhibits a linear response of $2 \mathrm{e}-4 \mathrm{mg} \mathrm{P} / \mathrm{l}$ for every \% reduction in 


\section{DISCUSSION}

The simulations for the rivers illustrate the differing effects of point and diffuse $\mathrm{P}$ sources on catchment water quality, and support the needs for multi-option, catchment based plans to effectively reduce overall riverine P concentrations. Applying the INCA-P model to the four test catchments and assessing the impact of substituting 50\% of inorganic P fertilizer used within the catchment with biosolids predicted variable decreases in TP and SRP within the catchments. The general reduction in phosphorus loss from agricultural as a result of substituting biosolids for inorganic phosphate fertilizers reflects the lower leaching potential of $\mathrm{P}$ from biosolids compared with inorganic phosphates (UKWIR, 1995). This is unsurprising as the biosolids themselves have an adsorption capacity not present in a mineral-based inorganic fertilizer. The amount of $\mathrm{P}$ lost via leaching will therefore be controlled by competition for adsorption sites determined by redox potential, $\mathrm{pH}$ and $\mathrm{Ca}$ concentrations, as well as soil properties such as water content, particle size and organic content. The ability of biosolids to retain $\mathrm{P}$ within their own matrix, whilst still making it available for plant growth means that they may be preferentially applied to agricultural land where application of inorganic fertilizer may result in leaching into adjacent watercourses (UKWIR, 2006).

The variation in the degree of $\mathrm{P}$ reduction within the catchment resulting from using biosolids rather than inorganic phosphate fertilizer may be a result of a number of possibilities:

- The Test and the Wensum with lower percentage reductions in concentrations being primarily chalk catchments with high base flow indices. This suggests that the biosolids effect will be less significant as nutrient reductions will be delayed by the longer residence times are longer.

- The Tywi with more surface water flows shows the highest effects reflecting the more rapid response of the catchment.

- The Lunan with an intermediate base flow index showing a moderate reduction.

It should also be noted that some variation in the solubility of biosolid $\mathrm{P}$ is to be expected, which will add some degree of uncertainty to the modelled $\mathrm{P}$ reductions.

Biosolids application cannot be seen as a panacea for the problems of disposing of WWTP P. Like the use of inorganic fertilizers, excessive application of biosolids have been linked to $\mathrm{P}$ concentration accumulating in soils in the US (Penn and Sims 2002, Shober and Sims 2003), New Zealand (Wang et al. 2008) and Australia (Pritchard et al. 2007). Different WWTP processes have different effects on $\mathrm{P}$ bioavailability and leaching as already discussed earlier (Penn and Sims 2002; Wang et al. 2008). Efforts must be made to balance P leaching rates against phytoavailability so as to ensure optimum plant growth while minimising leaching to receiving waters. 
It must be accepted, however, that there are a number of uncertainties impacting on the data generated from the model, including the leaching potential of the different types of biosolids, which (as has been explained in the introduction) will vary depending on its composition, the application process and soil type upon which it is applied. The model serves as a first step towards making informed decisions regarding catchment management.

Examining the more detailed outputs generated for the Wensum catchment suggests that further treatment of effluents at the largest WWTPs (2 and 4) would have a significant impact on downstream water quality, albeit at a significant cost without certainty of a change in ecological status. One option for more effective use tertiary treatment would be to undertake seasonallyadjusted phosphorus reduction at WWTP, with enhanced treatment in the summer when biological activity is greatest. The model outputs suggest that reducing phosphorus in the effluent to $0.25 \mathrm{mg} / \mathrm{l}$ would typically halve the concentrations in the catchment, to levels well below the current standard (0.12 mg-SRP/l) and below the high EQS status. Owing to higher flows in the winter, leading to greater dilution, then $\mathrm{P}$ dosing could be relaxed and still achieve the desired high EQS. An important aspect of any decision to move towards seasonal permitting is if there is a relaxation of permits during the winter, will $\mathrm{P}$ be stored in sediment downstream, only to be released sometime in the future? It is possible that $\mathrm{P}$ stored in the sediments will be released in the summer. However, it is also possible that less eutrophic conditions caused by lower summer $\mathrm{P}$ inputs will preserve well-oxygenated conditions and that the $\mathrm{P}$ will remain bound to the sediment.

This possible fate of sediment bound $\mathrm{P}$ would need to be considered on a case-by-case basis using models such as INCA-P which have a process component for predicting sediment-water interactions. Re-profiling the chemical dosing regime to allow seasonal permitting could lead to better environmental outcomes, in a cost-neutral way for Water Companies, at least in the interim until further source control measures are put in place to reduce phosphorus inputs to WWTP.

398 The other possible issue associated with seasonal permitting is that the WFD EQS is currently set 399 as an annual average (as are permit conditions). This means that relaxed winter permits could 400 401 402 403 404 405 406 lead to EQS exceedances during the winter which even with enhanced, sub-BAT phosphorus reduction in the summer could lead to an annual average phosphorus concentrations in the effluent being greater than the existing permit as well as in-river annual average levels greater than the EQS downstream Such a situation is not currently allowable in either the UWWTD or WFD. As such a significant re-assessment of the legislation would be required to potentially allow the widespread use of seasonal permitting in the UK, starting with an assessment of the diatom and macrophyte ecology downstream of the WWTP under varying permitting regimes.

The modelled scenarios also show that reducing agricultural discharges will have a significant impact on river concentrations, which is unsurprising as along with WWTP effluent input these are the dominant sources of phosphorus within the catchment (Comber et al., 2010). Overall, the data suggests that by taking a catchment-based view, it is possible to ensure compliance using seasonal-based permits, taking account of local situations associated with hydrology and ecology. Data such as that presented here, combined with cost-effectiveness of agricultural and effluent-based measures will allow planners to identify the most cost-effective, catchment based programmes of measures to assist in delivering WFD objectives. In all cases, owing to the 
variability in catchment hydrology and phosphorus sources, all options need to be considered on a catchment by catchment basis.

\section{CONCLUSIONS}

This study has shown that concentrations of $\mathrm{P}$ within four $\mathrm{UK}$ river catchments are dominated by WWTP effluent and agricultural sources. Consequently, control of these sources is essential to maintaining or restoring aquatic ecosystem health. The outputs from the scenarios modelled suggest there that substitution of inorganic fertilisers with biosolids, may not only be more sustainable (from a resource availability point of view) but offer the potential for reduced loss of $\mathrm{P}$ via runoff to adjacent water courses. The INCA-P modelling showed that for all four catchments, modelled substitution of inorganic fertilizer with biosolids results in a decrease in river concentrations, reflecting lower leaching rates. Variations are observed due to differences in land use and the balance between agricultural and diffuse inputs of phosphorus.

Furthermore, the modelling approach has been shown to be able to test scenarios for varying permitting regimes within a catchment in order to reduce phosphorus concentrations in the river during the summer months when eutrophication pressures are at their greatest. Comparing current annual average permit conditions versus innovative options such as seasonal permitting showed that summer river $\mathrm{P}$ concentrations can be lowered using tighter discharge limits, which can be relaxed in the winter during periods of higher flows without negatively effecting $\mathrm{P}$ concentrations in the receiving waters. Options such as there should be investigated further, to provide a more flexible approach (potentially at no overall increase in cost) to meeting WFD objectives.

\section{ACKNOWLEDGEMENTS}

The authors would like to thank UK Water Industry Research for funding this work, in particular to the project manager, Manocher Asaadi and the Project Steering Group members for assistance with data collection and interpretation. We would also like to acknowledge the assistance provided by SEPA regarding data supplied for the Lunan catchment in Scotland. We also acknowledge the assistance of the Environment Agency for access to river water quality and flow data.

\section{REFERENCES}

Alexander, R.B., Smith, R.A., Schwarz, G.E., Boyle, E.W., Noland, J.V., Brakebill, J.W., (2008) Differences in phosphorus and nitrogen delivery to the Gulf of Mexico from the Mississippi River Basin. Environmental Science and Technology 42, 822-830.

Carpenter, S.R., Caraco, N.F., Correll, D.L., Howarth, R.W., Sharpley, A.N. and Smith, V.H. (1998) Nonpoint pollution of surface waters with phosphorus and nitrogen. Ecological

Applications: Vol. 8, No. 3, pp. 559-568. doi: 10.1890/1051-0761(1998)008

CEEP (2009) Scope Newsletter Number 73.

CIWEM (2005) Policies: lead in drinking water (http://WWw.ciwem.org/policy-andinternational/policy-position-statements/lead-in-drinking-water.aspx) accessed 21/4/2012Cordell, D., Drangert, J.O. and White, S. (2009) The story of phosphorus: Global food security and food for thought, Global Environmental Change, 19, 292-305, DOI: 10.1016/j.gloenvcha.2008.10.009.

Comber S., Hope S-J., Piekarniak L., Whitehead P.G., and Blackwood D. (2010) Phosphorus Lifecycle Management, UKWIR Report 10/SL/02/9, ISBN 184057570 0, 75 pp. 
Cordell D. and White S. Peak Phosphorus: Clarifying the key issues of a vigorous debate about long-term phosphorus security. Sustainability 3 (2011), pp. 2027-2049.

Crossman, J., Whitehead, P.G., Futter M.N., Jin, L., Wade, A.J., Shahgedanova, M., Castellazzi, M. 2013. The implications of changes in climate, land use and water resource strategies for the effective management of phosphorus in the River Thames, Science of the Total Environment, 454-455 (2013) 230-244

Elliot, H.A., G.A. O'Connor, and S. Brinton. 2002. Phosphorus leaching from biosolids-amended sandy soils. J. Environ. Qual. 31:681-689.

EU (2000) The Water Framework Directive (Directive 2000/60/EC of the European Parliament and of the Council of 23 October 2000 establishing a framework for Community action in the field of water policy.

EU (1991) Urban Waste Water Treatment Directive (full title Council Directive 91/271/EEC of 21 May 1991 concerning urban waste-water treatment.

EU (1992) Habitats Directive: Council Directive 92/43/EEC on the Conservation of natural habitats and of wild fauna and flora.

Evans, T.D. (2001) Implications of within-WWTP P-recovery for biosolids management: biosolids volumes, N:P ratio \& recycling (agronomic, LCA and economic implications) a European perspective. Second international conference on recovery of phosphates from sewage and animal wastes Holland, 12-13 March 2001

Hayes C.R., Incledion, S. and Balch, M. 2008. Experience in Wales (UK) of the optimization of ortho-phosphate dosing for controlling lead in drinking water. Journal of Water Health 6:177-185.

Hogan F., McHugh M. and Morton S. (2001) Phosphorus availability for beneficial use in biosolids products. Presented at 12 - 13 March 2001 - Second International Conference On Phosphorus Recovery From Sewage And Animal Wastes, Noordwijkerhout.

Jarvie, H.P., Neal, C., Withers, P.J.A. (2006) Sewage effluent phosphorus: a greater risk to river eutrophication than agricultural phosphorus? Science of the Total Environment 360:246253.

Kostyanovsky K.I., Evanylo G.K., Lasley, K.K., Daniels W.L. and Shang C. (2011) Leaching potential and forms of phosphorus in deep row applied biosolids underlying hybrid poplar. Ecological Engineering 37, 1765- 1771.

Miller, M. and O'Connor, G.A. (2009) The longer-term phytoavailability of biosolidsphosphorus. Agronomy Journal 101:889-896.

Nixon SW (1995) Coastal marine eutrophication: a definition, social causes, and future concerns. Ophelia 41:199-219

Penn, C.J. and Sims, T.J. (2002) Phosphorus forms in biosolids-amended soils and losses in runoff: effects of wastewater treatment process, Journal of Environmental Quality, 31:1349-1361.

Pritchard, D., Penney, N., Bell, M. and Barry, G. (2007). Getting a grip on biosolids; the impact of phosphorus loading rates in Australia. In LeBlanc, R.J., Laughton, P.J. and Rajesh, T. (eds) Conference Proceedings Moving Forward, Wastewater Biosolids Sustainability: Technical, Managerial, and Public Synergy, International Water Association (IWA), Moncton, New Brunswick, Canada, 24-27 June 2007, on CD-Rom, pp 853-859

Richards I. R. and Johnston A. E., 2001. The effectiveness of different precipitated phosphates as sources of phosphorus for plants. Report on work undertaken for CEEP1, EFMA 
(European Fertilizer Manufacturers Association), Anglian Water UK, Thames Water UK and Berlin Wasser Betriebe.

Shober, A.L. and Sims, T,J. (2003) Phosphorus restrictions for land applications of biosolids: current status and future trends J Environ Qual 32:1955-1964.

Siddique, M.T., J.S. Robinson, and B.J. Alloway. 2000. Phosphorus reaction and leaching potential in soils amended with sewage sludge. J. Environ. Qual. 29:1931-1938.

Smith, S.R., Triner, N.G., Andrews, M.J., Johnson, A., Knight, J.J. (2000) Phosphorus release and fertiliser value of thermally dried and nutrient removal biosolids. 5th European Biosolids and Organic Residuals Conference CIWEM/AquaEnviro, 20-22 November (2000).

UKTAG (2013) Phosphorus Standards For Rivers. Updated Recommendations

UK Technical Advisory Group August 2013.

UKWIR (1995) The Environmental Impact of Phosphorus from the Agricultural Disposal of Sewage Sludge - Stage 2. Impact of Phosphorus SL-02. UKWIR, London.

UKWIR (1997) The Environmental Impact of Phosphorus from the Agricultural Use of Sewage Sludge - Final Report: Sewage Sludge SL-02. UKWIR, London.

UKWIR (2004) Application of Phosphorus in Industrial Biosolids Applied to Agricultural Soils - Review. Sewage Sludge: Nutrients SL/02. UKWIR, London.

UKWIR (2006) Application of Phosphorus in Biosolids to Agricultural Soils. UKWIR, London. UKWIR (2010) WW/23 Better regulation: integrated catchment regulation, April 2010.

UKWIR/SNIFFER/UKTAG. (2008) Final Report: Source Control of Phosphorus from Domestic Sources - Options and Impacts. UKWIR Ltd.

White, P.J. and Hammond, J.P. (2009) The Sources of Phosphorus in the Waters of Great Britain, Journal of Environmental Quality, 38:13-26 DOI: 10.2134/jeq2007.0658

Wade AJ, Hornberger GM, Whitehead PG, Jarvie HP, Flynn N. (2001) On modeling the mechanisms that control in-stream phosphorus, macrophyte, and epiphyte dynamics: An assessment of a new model using general sensitivity analysis, Water Resources Research; 37: 2777-2792.

Wade, A.J., P.G. Whitehead and D. Butterfield. (2002) The integrated catchments model of phosphorus dynamics (INCA-P), a new approach for multiple source assessment in heterogeneous river systems: model structure and equations, Hydrol. Earth Sys. Sci. 6 583-606.

Wade AJ, Butterfield D, Lawrence DS, Bärlund I, Ekholm P, Lepistö A, Yli-Halla M, Rankinen K, Granlund K, Durand P, et al. 2009. The Integrated Catchment Model of Phosphorus (INCA-P), a new structure to simulate particulate and soluble phosphorus transport in European catchments, Deliverable 185 to the EU Euro-limpacs project, UCL, London, pp 67.

Wang, H., Brown, S.L., Magesan, G.N., Slade, A.H., Quintern, M., Clinton, P.W. and Payn, T.W. (2008) Technological options for the management of biosolids. Environ Sci Pollut Res, 15:308-317.

White P.J. and Hammond H.P. (2007) Updating the estimate of the sources of phosphorus in UK waters. Defra project WT0701CSF.

Whitehead PG, Wilson EJ, Butterfield D. (1998a) A semi-distributed Integrated Nitrogen model for multiple source assessment in Catchments (INCA): Part I - model structure and process equations. Science of the Total Environment ; 210: 547-558. 
Whitehead PG, Wilson EJ, Butterfield D, Seed K. (1998b A semi-distributed integrated flow and nitrogen model for multiple source assessment in catchments (INCA): Part II application to large river basins in south Wales and eastern England. Science of the Total Environment; 210: 559-583.

Whitehead PG, Jin L, Baulch HM, Butterfield DA, Oni SK, Dillon PJ, Futter MN, Wade AJ, North R, O'Connor EM, Jarvie HP (2011) Modelling phosphorus dynamics in multibranch river systems: a study of the Black River, Lake Simcoe, Ontario, Canada. Science of the Total Environment: 15;412-413:315-23

Whitehead, PG., Crossman J, Balana BB, Futter MN, Comber S, Jin L, Skuras D, Wade AJ, Bowes MJ, Read DS. (2013) A cost-effectiveness analysis of water security and water quality: impacts of climate and land-use change on the River Thames system." Philosophical Transactions of the Royal Society A: Mathematical, Physical and Engineering Sciences 371, no. 2002: 20120413. 